Int. J. Electrochem. Sci., 11 (2016) $9519-9528$

\title{
Electrochemical Behavior of Crude Extract of Brosimum gaudchaudii and Its Major Bioactives, Psoralen and Bergapten
}

\author{
Morgana Fernandez Alecrim ${ }^{1}$, Germán Sanz Lobón, ${ }^{1,2}$, Rúbia D'Arc Machado ${ }^{1}$, Edilson Ribeiro de \\ Oliveira Júnior ${ }^{1}$, Ruiter Lima Morais ${ }^{1}$, Kênnia Rocha Rezende ${ }^{1}$, Boniek Vaz Gontijo ${ }^{2}$, \\ Wallans Torres Pio dos Santos ${ }^{3}$, Eric de Souza Gi1 ${ }^{1 *}$ \\ ${ }^{1}$ Faculdade de Farmácia and ${ }^{2}$ Instituto de Química, Universidade Federal de Goiás, Rua 240 com 5a \\ avenida, Setor Universitário, Goiânia, Goiás, Brasil \\ ${ }^{3}$ Departamento de Farmácia, Universidade Federal dos Vales do Jequitinhonha e Mucuri, Campus JK, \\ 39100-000 Diamantina, MG, Brasil \\ *E-mail: ericsgil@ufg.br
}

doi: $10.20964 / 2016.11 .31$

Received: 14 July 2016 / Accepted: 2 September 2016 / Published: 10 October 2016

Roots from Brosimum gaudchaudii Trécul (Moraceae), popularly known as Mama-Cadela, is a traditional medicinal shrub from Brazilian "Cerrado" widely used in the photochemotherapy of vitiligo. Their main actives are the prenylated coumarins, Psoralen (Ps) and bergapten (Bp), which under UV exposure generate active compounds that form adducts with DNA. Though such reactions may involve electron transfer reactions, the redox behavior of BGT and their major isolated furanocoumarins, remain unknown. Therefore the aim of this study was to evaluate the electrochemical behavior of Ps, Bp and crude extracts of BGT by means of voltammetry. The cyclic voltammograms performed for $\mathrm{Bp}$ and $\mathrm{Ps}$, confirmed the electroactivity only for $\mathrm{Bp}$, which presented a anodic peak potential at $E_{\mathrm{p} 1 \mathrm{a}}=1.2 \mathrm{~V}$. Similar behavior was observed for the BGT crude extract. In turn, from the differential pulse voltammograms (DPV), it was observed two small anodic peaks, 1a and 2a at lower peak potentials, which are consistent with hydroquinone and catechol like compounds. Also, it was observed that the main anodic peak occurred close to the Bp peak potential, 1a, whereas no peak was observed for Ps. Therefore, from voltammetric assays, it could be inferred that Bp is present in BGT crude extracts, which were corroborated by HPLC coupled to mass spectrometry. An cheaper and simpler electroanalytical procedure was proposed in order to estimate the amount of Bp in BGT, which despite the low repeatability presented comparable recovery compared to HPLC-PDA.

Keywords: Bergapten, Psoralen, Vitiligo, Psoriasis, Mama-cadela

\section{$\underline{\text { FULL TEXT }}$}


(C) 2016 The Authors. Published by ESG (www.electrochemsci.org). This article is an open access article distributed under the terms and conditions of the Creative Commons Attribution license (http://creativecommons.org/licenses/by/4.0/). 